\title{
PENEGAKAN HUKUM PIDANA LINGKUNGAN TERHADAP PELAKU TINDAK PIDANA PEMBALAKAN LIAR
}

\section{ENFORCEMENT OF ENVIRONMENTAL CRIMINAL LAW AGAINST CRIMINALS OF ILLEGAL LOGGING}

\author{
Erlina B \\ Fakultas Hukum Universitas Bandar Lampung \\ Erlina.B@ubl.ac.id \\ Okta Ainita \\ Fakultas Hukum Universitas Bandar Lampung \\ okta.ainita@ubl.ac.id \\ Fissabilla Rima Novita \\ Fakultas Hukum Universitas Bandar Lampung \\ fissabilla.17211198@student.ubl.ac.id
}

\begin{abstract}
Abstrak
Fokus utama penelitian ini adalah faktor penyebab tindak pidana turut serta memasarkan kayu dari pembalakan liar dan penerapan hukum pidana lingkungan terhadap pelaku tindak pidana turut serta memasarkan kayu berasal dari pembalakan liar. Metode penelitian yang digunakan dalam penelitian adalah yuridis normatif dan empiris. Berdasarkan hasil penelitian yang didapat bahwa penyebab terjadinya pembalakan liar di Desa Cikolak Teluk Pandan, Kabupaten Pesawaran, meliputi faktor internal antara lain faktor pendidikan, faktor personal, faktor patogen biologis dan pneumonia. Faktor eksternal meliputi faktor lingkungan, kurangnya perlindungan, kurangnya pemberdayaan masyarakat, faktor pembangunan global dan faktor ekonomi. Penegakan hukum Pidana lingkungan terhadap pelaku tindak pidana turut serta memasarkan kayu yang berasal dari pembalakan liar yakni pidana penjara selama 1 (satu) tahun dan denda sebesar Rp. 500,000,000.00 (lima ratus juta rupiah) dengan ketentuan apabila denda tersebut tidak dibayar maka diganti dengan pidana penjara selama 2 (dua) bulan.
\end{abstract}

Kata Kunci: Tindak Pidana, Pembalakan Liar, Hutan, Hukum.

\begin{abstract}
The main focus of this research is the factors that cause criminal acts, participate in marketing timber from illegal logging and the application of environmental criminal law to the perpetrators of criminal acts and participate in marketing timber from illegal logging. The research method used in this research is juridical normative and empirical. Based on the
\end{abstract}


research results, it was found that the causes of illegal logging in Cikolak Teluk Pandan Village, Pesawaran District, included internal factors including educational factors, personal factors, biological pathogenic factors and pneumonia. External factors include environmental factors, lack of protection, lack of community empowerment, global development factors and economic factors. Enforcement of environmental criminal law against perpetrators of criminal acts by participating in marketing timber from illegal logging, namely imprisonment for 1 (one) year and a fine of Rp. 500,000,000.00 (five hundred million rupiah) provided that if the fine is not paid, it will be replaced by imprisonment for 2 (two) months.

Keywords : Crime, Illegal Logging, Forest, Law

\section{A. Pendahuluan}

Kerusakan kehidupan sosial budaya dan lingkungan hidup, serta meningkatkan pemanasan global yang telah menjadi isu nasional, regional dan internasional. ${ }^{1}$ Kegiatan terorganisir dilakukan oleh kelompok terstruktur yang terdiri dari dua orang atau lebih yang bertindak secara kolektif pada waktu tertentu dengan tujuan untuk merusak hutan, tetapi tidak tinggal di kawasan atau kelompok masyarakat terdekat. Hutan yang digunakan dalam pertanian tradisional atau penebangan untuk tujuan tradisional atau nonkomersial. $^{2}$

Amanat peraturan Perundang-

1 Rayhan Wangke, Penegahan dan Pemberantasan Pembalakan Liar, Jurnal Kerjasama Bilateral Sumatra Selatan dan Kalimantan Barat Oleh DPR Provinsi, Vol 30, Nomor 12, 2018, hlm 18.

${ }^{2}$ Ibid undangan di Indonesia. Harapan untuk mengelola sumber daya hutan Indonesia melalui partisipasi masyarakat atau partisipasi aktif. Adapun amanat tersebut secara tegas disampaikan melalui Undang-Undang Nomor 41 Tahun 1999 tentang Kehutanan jo. Undang-Undang Nomor 18 tahun 2013 tentang Pencegahan Pemberantasan Perusakan Hutan, serta Undang-Undang Nomor 5 Tahun 1990 tentang Konservasi Sumber Daya Alam Hayati dan Ekosistemnya, Diantaranya, kedua undang-undang tersebut mengatur tentang perlindungan alam kawasan hutan nasional.Hutan nasional tidak hanya mencakup perlindungan keanekaragaman hayati, tetapi juga mencakup fungsi penyangga kehidupan yang diperlukan untuk melindungi kawasan hutan. Pasal 30 Undang-Undang Nomor 05 Tahun 1990 tentang Konservasi Sumber Daya Alam 
Hayati dan Ekosistemnya.

Menurut sifat, karakteristik dan kerentanannya untuk mengkoordinasikan keseimbangan lingkungan, hutan dibedakan menjadi tiga fungsi utama yaitu hutan lindung, hutan lindung dan hutan produksi. Kemudian melakukan standarisasi pengelolaan setiap fungsi hutan utama dalam rangka mewujudkan prinsipprinsip pengelolaan hutan lestari.

Dalam rangka mengoptimalkan fungsi dan manfaat hutan dan kawasan hutan harus sesuai dengan kewenangan Undang-Undang Kehutanan, dan pada prinsipnya nama atau fungsi kawasan hutan dapat diubah sesuai dengan dinamika pembangunan nasional dan keinginan masyarakat. Untuk menjaga keseimbangan antara manfaat lingkungan, manfaat sosial budaya dan manfaat ekonomi, maka penamaan dan fungsi kawasan hutan harus dilandasi secara lestari dan lestari untuk mengoptimalkan sebaran fungsi dan manfaat kawasan hutan. Suatu kawasan hutan dengan skala dan proporsi yang cukup. $^{3}$

${ }^{3}$ Erlina B, Bambang Hartono, Anggalana, Melisa Safitri. Optimalisasi Nilai Kearifan Lokal Rembug Pekon Dalam Pengelolaan Taman Hutan Raya (Tahura) Wan
Hutan merupakan anugerah dari Tuhan Yang Maha Esa, kekayaan yang dikuasai negara, dan memberikan banyak manfaat bagi umat manusia, oleh karena itu harus diapresiasi, dikelola dan dimanfaatkan secara maksimal, serta harus diwariskan untuk melindungi umat manusia dari generasi ke generasi sekarang dan di masa yang akan datang. Fungsi hutan ini pada dasarnya adalah modal alam. Tujuannya antara lain: melindungi lingkungan, meningkatkan pendapatan nilai tambah, mendorong ekspor nonmigas, gas alam, menyediakan lapangan kerja, dan mendorong pembangunan sektor non kehutanan. $^{4}$

Oleh karena itu, jelas terlihat bahwa pada hakikatnya illegal logging adalah semua kegiatan yang menggunakan hasil kayu illegal yang terorganisir. Penebangan liar merupakan suatu perilaku yang dapat merugikan lingkungan, terutama sebagai kawasan

Abdurahman Propinsi Lampung Sebagai Kawasan Hutan Konservasi Berbasis Masyarakat, Jurnal Fakultas Hukum Universitas Bandar Lampung Volume 9 Nomor 2 2018, hlm 102.

${ }^{4}$ Zul Akrial, Tindak Pidana Kehutanan (Illegal Logging) di Indonesia, (Jakarta : Graha Yustika, 2015).HIm. 29. 
hutan di paru-paru dunia, sehingga mengakibatkan efek berbahaya bagi kehidupan manusia, hewan dan tumbuhan. Penebangan dan pemanfaatan kayu hasil penebangan merupakan perilaku yang sangat buruk, apalagi jika oknum-oknum yang tidak bertanggung jawab terus melakukan penebangan. ${ }^{5}$

Menganalisis perilaku kriminal dari keikutsertaan dalam penjualan kayu melalui penebangan liar, bertujuan untuk menghapuskan kejahatan hutan terorganisir dan kejahatan hutan yang dilakukan oleh perusahaan. Undangundang tidak dimaksudkan untuk mengkriminalisasi petani kecil yang tinggal di dalam atau sekitar hutan dan berkebun.

Kegiatan terorganisir dilakukan oleh kelompok terstruktur yang terdiri dari dua orang atau lebih, kegiatan tersebut bekerja sama pada waktu tertentu dengan tujuan untuk merusak hutan, tetapi tidak termasuk kelompok masyarakat yang tinggal di kawasan atau kawasan sekitarnya. Hutan yang melakukan pertanian tradisional dan /

5 Elvira, Pola Jaringan Pembalakan Liar Jurnal Kriminologis Indonesia, Volume 8 No 2 2017, hlm 9. atau penebangan untuk kebutuhan sendiri dan bukan untuk tujuan komersial. $^{6}$

Berdasarkan latar belakang di atas, maka penulis mengangkat permasalahan sebagai berikut faktor penyebab terjadinya tindak pidana turut serta memasarkan kayu dari pembalakan liar dan penerapan sanksi pidana lingkungan terhadap pelaku tindak pidana turut serta memasarkan kayu berasal dari pembalakan liar.

\section{B. Metode Penelitian}

Dalam membahas permasalahan yang terdapat dalam penelitian maka dilakukan dengan metode yuridis normatif dan yuridis empiris guna untuk medapatkan suatu hasil penelitian yang benar dan objektif. Metode yuridis normatif dilakukan melalui studi kepustakaan (Library Research) terhadap hal-hal yang bersifat teoritis dengan mempelajari asas-asas hukum dalam teori atau pendapat sarjana dan peraturan perundang-undangan yang berlaku. Yuridis Empiris dilakukan melalui penelitian secara langsung

6 Undang-Undang Nomor 18 tahun 2013 tentang Pencegahan Pemberantasan Perusakan Hutan 
terhadap objek penelitian dengan cara observasi dan wawancara. Mengenai penegakan hukum lingkungan terhadap tindak pidana turut serta memasarkan kayu yang berasal dari kawasan hutan yang diambil atau dipungut secara tidak sah yang diketahui berasal dari pembalakan liar berdasarkan (Putusan Nomor :792/PID.B.LH/2020/PN.TJK)

\section{Pembahasan}

\section{Faktor Penyebab Terjadinya Tindak Pidana Turut Serta Memasarkan Kayu Dari Pembalakan Liar.}

Pada bagian ini dipaparkan beberapa faktor yang dimulai dengan faktor internal dan faktor eksternal. Faktor internal antara lain faktor pendidikan yang menjadi salah satu faktor yang mendorong masyarakat melakukan tindak pidana illegal logging. Hal ini disebabkan minimnya pengetahuan mereka tentang aturan-aturan kehidupan sosial. Tingkat pendidikan dianggap sebagai salah satu faktor yang mempengaruhi perilaku seseorang. Pendidikan merupakan sarana bagi seseorang untuk melakukan tindakan untuk menentukan apakah suatu perilaku bermanfaat atau bahkan menimbulkan masalah atau kerugian tertentu untuk memahami baik dan buruk. Selain itu juga menunjukkan persepsi masyarakat tentang apa yang baik dan apa yang buruk.

Faktor Individu, orang yang bertingkah laku baik akan menyebabkan seseorang dihormati oleh masyarakat, namun sebaliknya jika seseorang berperilaku tidak benar maka akan menimbulkan kekacauan sosial. Mereka yang dapat mengontrol dan mengembangkan kepribadian yang positif akan dapat membawa banyak manfaat bagi dirinya dan orang lain. Pada saat yang sama, mereka yang tidak dapat mengontrol kepribadiannya dan cenderung terpengaruh oleh perkembangan akan terus tertarik pada tren. Baik atau buruk, mereka akan terus melakukannya. Sebagaimana telah isinggung di atas, ada juga alasan seseorang melakukan kejahatan, yaitu keinginan manusia yang tidak terbatas.

Berdasarkan teori biologis bahwa faktor fisiologis manusia dan struktur tubuh dimulai sejak lahir. Melalui gen dan warisan, penyimpangan perilaku dapat disebabkan. Pewarisan tren tipe abnormal dapat menghasilkan perilaku abnormal dan mengarah pada perilaku sosial. Misalnya, cacat bawaan yang berkaitan dengan karakteristik kriminal dan penyakit jiwa. Orang tua bertanggung 
jawab atas tingkah laku anaknya Ada pepatah: "Buah tidak jauh dari pohonnya." Oleh karena itu perilaku atau kebiasaan orang tua dalam keluarga sangat menentukan sifat anak dalam komunikasi interpersonal. Selain itu, cara orang tua dalam mendidik anaknya juga berpengaruh pada hakikat anaknya di masyarakat.

Berdasarkan teori psikogenesis bahwa perilaku kriminalitas ada lantaran faktor intelegensi, karakteristik kepribadian, motivasi, perilaku-perilaku fantasi, rasionalisasi, internalisasi diri yang keliru, pertarungan batin, emosi yang kontroversial dan kesamaan psikopatologis, ialah kondisi dursila adalah reaksi terhadap perkara psikis, contohnya dalam keluarga dampak perceraian atau salah asuhan lantaran orang tua terlalu sibuk berkarier. Faktor lain yang menjadi penyebab terjadinya kejahatan adalah psikologis dari seorang pelaku kejahatan. Faktor ini didominasi karena pribadi seseorang yang tertekan dengan keadaan hidupnya yang tak kunjung membaik atau frustasi. Psikologis seseorang yang terganggu dalam interaksi sosial akan tetap memiliki kelakuan jahat tanpa melihat situasi dan kondisi. Pelaku kejahatan cenderung memiliki psikologis yang sedang dalam keadaan tertekan untuk memenuhi kebutuhan hidupnya yang tak kunjung dapat ia lakukan karena tak memiliki penghasilan tetap.

Kemiskinan atau faktor ekonomi ini menjadi faktor yang memengaruhi terjadinya kejahatan, karena demi memenuhi kebutuhan hidupnya maka orang akan cenderung melakukan apapun itu meski melakukan kejahatan sekalipun. Faktor lingkungan merupakan salah satu faktor yang memiliki pengaruh atas terjadinya tindak pidana pembalakan liar. Seseorang yang hidup atau tinggal di dalam lingkungan yang mendukung untuk dilakukannya pencurian, maka di suatu waktu pencurian. Banyak hal yang membuat lingkungan menjadi faktor penyebab terjadinya suatu tindak kejahatan.

Faktor kurangnya penjagaan kawasan dan pada jam-jam tertentu yang menjadi kesempatan para pelaku pembalakan liar sehingga pelaku secara bebas dari satu wilayah ke wilayah lain dapat mengangkut kayu karena tidak adanya penjagaan di saat tertentu, tidak takut dan merasa bebas untuk melakukan aksinya. Berdasarkan data yang diperoleh oleh peneliti dari hasil wawancara dengan Penyidik Dinas Kehutanan Provinsi Lampung yang diwawancarai oleh 
penulis bahwa para pelaku tindak pidana pembalakan liar mengangkut kayu dari hasil pembalakan liar menggunakan mobil dengan nomor plat dengan ditutupi kain putih dan pada saat pengeledahan ditemukan surat angkut yang tidak sesuai dengan tujuan perjalanan mereka. Hal tersebut menunjukkan bahwa kurang ketatnya penjagaan daerah tertentu dan pada saat jam tertentu. Seharusnya penjagaan dan pengawasan lebih di perketat lagi. Sistem pengawasan oleh aparatur masih belum berjalan dengan baik, sehingga apabila terjadi pelanggaran dan penyimpangan yang dilakukan oleh oknum aparatur tertentu maka akan sulit untuk ditetapkan sebagai saksi yang jelas.

Faktor pemberdayaan masyarakat di sekitar elemen hutan belum optimal. Pemberdayaan masyarakat merupakan wadah yang menjamin kemandirian perilaku, aksi dan refleksi, tidak terbatas pada kondisi kehidupan material, dan yang terpenting tidak berada dalam jaringan sistem politik resmi (negara). Pengalaman berbagai daerah dan wilayah Lampung sendiri menunjukkan bahwa kontribusi kelembagaan masyarakat dalam mendorong pembangunan partisipatif sangat penting.

Faktor perkembangan global berdampak positif bagi kemajuan suatu negara, dan bagi seorang individu, perkembangan global merupakan sarana untuk menunjukkan bahwa dirinya adalah orang yang dapat memenuhi kebutuhannya sendiri dalam masa perkembangan global ini. Selain memiliki orang yang lebih dianggap sebagai orang sukses, hal ini tentunya akan membuat setiap orang di masyarakat saling bersaing untuk menunjukkan bahwa dirinya yang terbaik. Tidak dapat dipungkiri bahwa meskipun orang yang tidak kompeten menggunakan cara yang salah sebelumnya, mereka akan tetap mengikuti kompetisi. Kebanyakan dari mereka lebih memilih metode praktis, daripada harus bekerja lebih keras, tanpa harus mempertimbangkan risiko yang akan mereka ambil di masa depan akibat tindakan yang mereka ambil. Ini seperti salah satu pelaku kejahatan illegal logging. Kemajuan teknologi, khususnya kemajuan media massa, turut mempengaruhi seseorang untuk berbuat jahat. Media massa merangsang pemikiran masyarakat dalam kehidupan sosial. Bahkan tidak jarang program televisi memberikan contoh, meskipun pada dasarnya program tersebut tidak dimaksudkan untuk memberikan contoh. Kemampuan berpikir dan mempersepsikan setiap orang pasti 
berbeda- beda, sehingga suatu acara TV dapat meninggalkan kesan yang buruk pada seseorang.

Faktor ekonomi faktor utama terjadinya pencurian kayu, terutama di antara masyarakat yang tinggal di sekitar atau di dalam kawasan hutan. Mendorong mereka mencuri kayu di kawasan hutan hanya untuk memenuhi kebutuhan seharihari. Faktor ekonomi selalu menjadi alasan bagi masyarakat sehingga mereka sangat mengandalkan mata pencahariannya untuk menebang pohon. Tekanan ekonomi (kemiskinan) dan minimnya kesempatan kerja, pendidikan dan keterampilan yang rendah, serta kurangnya modal usaha membuat mereka menjadi penebang pohon. Sebagian besar masyarakat Desa Cikolak Teluk Pandan di Kabupaten Pesawaran telah bekerja di sektor perkayuan secara turun temurun, bahkan beberapa remaja sudah mulai bekerja di bidang tersebut. Oleh karena itu, masyarakat percaya bahwa mereka tidak memiliki keterampilan kerja lain selain menebang pohon, sehingga sulit untuk meninggalkan pekerjaan tersebut. Menurut Kementerian Kehutanan, sekitar 60 juta orang Indonesia bergantung pada hutan untuk mata pencaharian mereka. Kebanyakan dari mereka termasuk kelas pra-sejahtera.
2. Penerapan Hukum Pidana

Lingkungan Terhadap Pelaku Tindak Pidana Turut Serta Memasarkan Kayu Berasal Dari

\section{Pembalakan Liar.}

Dalam melakukan penangkapan dan penahanan, penyidik pegawai negeri berkoordinasi dengan penyidik dari Kepolisian Negara Republik Indonesia. Setelah pelaku menyelesaikan prosedur investigasi, dia membawanya ke kantor kejaksaan untuk mengajukan gugatan, dan kemudian menyerahkan kasus tersebut ke pengadilan untuk diadili. Menggunakan alat bukti di pengadilan untuk menentukan kejahatan pelaku. Jika jaksa menuduh pelaku bersalah, maka pengadilan akan menjatuhkan hukuman penjara sesuai dengan ketentuan. Sebaliknya, jika terdakwa tidak dapat dibuktikan bersalah, pengadilan akan membebaskannya.

Penerapan Hukum Pidana Lingkungan Terhadap pelaku tindak pidana turut serta memasarkan kayu berasal dari pembalakan liar. Hutan sebagai sumber daya alam hayati memiliki arti dan nilai strategis. Nilai strategis hutan sebagai sumber daya alam yang dapat memberikan berbagai manfaat bagi kehidupan manusia. Manfaat ekologi, sosial dan ekonomi 
adalah tiga pilar yang dapat memperoleh manfaat dari hutan. Nilai strategis hutan juga dapat didefinisikan dari perspektif ekonomi sebagai masukan sumber daya untuk mendorong pembangunan ekonomi dan sosial. Artinya, tidak dapat dipungkiri bahwa hutan merupakan sumber daya yang vital bagi perekonomian Indonesia. $^{7}$

Secara konsepsional, maka inti dan arti Penegakan hukum terdiri dari kegiatan pemisahan relasi nilai, relasi nilai tersebut ditransformasikan menjadi prinsip dan sikap yang kokoh dan terwujud, yang menjadi rangkaian definisi nilai akhir untuk menciptakan, memelihara, dan memelihara kehidupan sosial yang damai. ${ }^{8}$

$$
\text { Penegakan hukum Pidana }
$$
lingkungan terhadap pelaku tindak pidana turut serta memasarkan kayu yang berasal dari pembalakan liar. Penjatuhan pidana penjara selama 1 (satu) tahun dan denda sebesar Rp. 500,000,000.00 (lima ratus juta rupiah) dengan ketentuan

\footnotetext{
${ }^{7}$ Titi Puspawati, Ekosistem Hutan dan Paru-
} Paru dunia, (Malang : Universitas Negeri Malang Press, 2017), .hlm. 271.

8 Absori, Khudzaifah Dimyati dan Kelik Wardiono. 2018. Model Penyelesaian Sengketa Lingkungan Melalui Lembaga Alternatif, Mimbar Hukum, Volume 20, Nomor 2, Juni 2018. HIm. 367. apabila denda tersebut tidak dibayar maka diganti dengan pidana penjara selama 2 (dua) bulan.

Dalam hal terjadi pelanggaran, hukum pidana harus ditegakkan. Ketika penuntut umum atau negara yang diwakili oleh jaksa melanggar hukum pidana nasional, bagaimana seharusnya negara menegakkan hukum pidana). Dugaan sumber pembalakan liar dengan menggunakan hasil hutan kayu terjadi tidak hanya di satu kawasan hutan di Indonesia, tetapi juga di beberapa kawasan hutan. Selain itu, pemerintah telah memberikan payung hukum untuk mencegah dan memberantas kerusakan hutan oleh oknum-oknum yang tidak bertanggung jawab. Perlu adanya kesadaran diri untuk mendukung aturan agar berjalan dengan baik.

Salah satu landasan pemidanaan adalah perlindungan hukum, yaitu melalui pemidanaan terhadap orang yang menghambat tercapainya harapan hidup, terwujud tujuan hidup dan hidup bersama dalam bentuk perlindungan hukum, sehingga terwujudnya ketertiban hukum. Teori-teori yang terkandung dalam teori obyektif memberikan justifikasi untuk perlindungan komunitas atau pencegahan kejahatan. Pelaku tindak pidana tidak akan mengulangi perbuatannya. 
Pencegahan terjadinya tindak pidana dilakukan dengan memasukkan ancaman pidana termasuk batasan minimal dan maksimal bagi pelaku dengan pidana penjara dan / atau denda. Jika seluruh masyarakat memahami hal tersebut, maka pelanggaran tidak akan terjadi.

\section{Kesimpulan}

Dari

pembahasan tentang kemungkinan faktor penyebab tindak pidana pembalakan liar di Desa Cikolak Teluk Pandan Kabupaten Pesawaran terdapat beberapa faktor internal antara lain, faktor pendidikan, faktor individu, faktor kriminogen (bawaan dari lahir) biologis dan, pisigonesis. Faktor eksternal antara lain, faktor lingkungan, faktor kurangnya penjagaan, faktor kurangnya pemberdayaan masyarakat, faktor perkembangan global, dan faktor ekonomi. Sebagaimana diatur dalam Pasal 87 ayat (1) huruf B jo. Pasal 12 huruf I Undang- Undang Nomor 18 Tahun 2013 tentang Pencegahan dan Pemberantasan Perusakan Hutan jo. Pasal 55 ayat (1) ke-1 Kitab Undang-Undang Hukum Pidana, adalah sebagai berikut: Penegakan hukum Pidana lingkungan terhadap pelaku tindak pidana turut serta memasarkan kayu yang berasal dari pembalakan liar. Dengan dijatuhi pidana penjara selama 1 (satu) tahun dan denda sebesar Rp. 500,000,000.00 (lima ratus juta rupiah) dengan ketentuan apabila denda tersebut tidak dibayar maka diganti dengan pidana penjara selama 2 (dua) bulan.

\section{Daftar Pustaka}

\section{Buku}

Rayhan Wangke, Penegahan dan Pemberantasan Pembalakan Liar, Jurnal Kerjasama Bilateral Sumatra Selatan dan Kalimantan Barat Oleh DPR Provinsi, Vol 30, Nomor 12, 2018 .

Titi Puspawati, Ekosistem Hutan dan Paru-Paru dunia, Malang : Universitas Negeri Malang Press, 2017

\section{Zul Akrial, Tindak Pidana Kehutanan (Illegal Logging) di Indonesia, Jakarta : Graha Yustika, 2015.}

\section{Karya Ilmiah}

Erlina B, Bambang Hartono, Anggalana, Melisa Safitri, Optimalisasi Nilai Kearifan Lokal Rembug Pekon Dalam Pengelolaan Taman Hutan Raya (Tahura) Wan Abdurahman Propinsi Lampung Sebagai Kawasan Hutan Konservasi Berbasis Masyarakat, Volume 9 Nomor 2, Jurnal Fakultas Hukum Universitas Bandar Lampung, 2018. 
Elvira, Jurnal Kriminologis Indonesia Tentang Pola Jaringan Pembalakan Liar, Universitas Indonesia, Fakultas Hukum Universitas Indonesia. Volume 8 No 2, 2017.

Absori, Khudzaifah Dimyati dan Kelik Wardiono, Model Penyelesaian Sengketa Lingkungan Melalui Lembaga Alternatif, Mimbar Hukum, Volume 20, Nomor 2, Juni 2018.

\section{Peraturan Perundang-Undang}

Undang-Undang Nomor 18 tahun 2013 tentang Pencegahan Pemberantasan Perusakan Hutan 